\title{
(5)

\section{Skal jeg noen gang kunne føle meg som lege?}

LEGELIVET

VICTORIA SCHEI

E-post: victoria.schei.92@gmail.com

Victoria Schei er sjetteårs medisinstudent ved Universitetet i Bergen.

Som blivende lege har jeg følt på et slags bedragersyndrom gjennom hele medisinstudiet. Jeg er jo bare en lekperson som går på forelesninger, leser til eksamener, øver på pasientmøter.

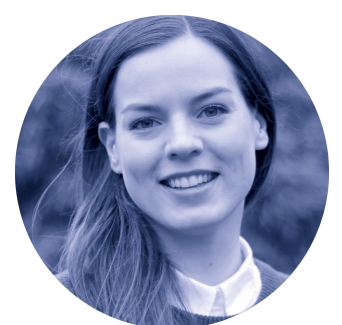

Foto: Sondre Hansmark

Men når blir jeg lege? Kanskje jeg bare blir en bløff? Underbevisst har utryggheten blitt en selvfølge. Helt til det skjedde noe i allmennpraksis i høst.

«Er det ikke skummelt å tenke på at du snart er ferdig lege?» spør folk når de hører jeg er på siste studieår. Og jo, det er skummelt. Kravene har gitt meg avmaktsfølelse siden første studiedag. Vi skal forstå og huske kompleks anatomi, fysiologi og farmakodynamikk samt symptomer, tegn, mekanismer og behandlingsalgoritmer for de merkeligste sykdommer $\mathrm{i}$ alle kroppens organer. Kan i det hele tatt et vanlig menneske klare alt det? Rundt meg ser det ut som om alle andre enn jeg fikser denne jobben, og i mørke timer under eksamenspuggingen har jeg visst at jeg valgte feil yrke - jeg klarer jo ikke å få dette til å feste seg i hodet mitt. I pasientsituasjoner har jeg blitt flau og nedsunket når jeg ikke får utløst akillessenerefleksen, når jeg reagerer på en klump på halsen som ifølge legen bare er en vanlig lymfeknute, eller når kommunikasjonen blir keitete og klein. I den mentale brønnen er det mørkt å være.

I den mentale brønnen er det mørkt å være

Utryggheten lå tungt i magen da jeg skulle prøve meg i fastlegens sko i seks uker. Da jeg gikk ut på venterommet og hentet Jonas 26 år med «skulder», visste jeg at jeg ikke ville få det til. Skulder hadde jeg jo knapt fått lest på! Det nølende kroppsspråket til Jonas avslørte at han langt heller ville snakke med fastlegen, og jeg var egentlig enig. Hva skulle han med ubrukelige meg? Jeg satte opp min profesjonelle maske og lot som om jeg hadde gjort dette 
tusen ganger før. Men utryggheten fikk meg til å famle i konsultasjonen, stoppe opp, unnskylde meg, le høflig mens jeg småsvett søkte etter «skulderdiagnostikk» på Norsk Elektronisk Legehåndbok. Utryggheten pustet meg i nakken da jeg undersøkte Jonas med skjelvende studenthender, uten å ta tørre å ta ordentlig på ham.

Utryggheten tok trykkende plass i rommet mens Jonas ventet på at jeg skulle si hva som feilet ham og hva som kunne gjøres med det. Egentlig ville jeg bare trykke på pause, så jeg fikk lest meg opp. Egentlig ville jeg bare klare det perfekt. Egentlig ville jeg være ferdig lege med 20 års erfaring. Og slippe denne ekle følelsen av å luske inn til veileder med halen mellom beina uten å ane hva som var galt med skulderen.

En dag merket jeg at jeg faktisk tok ledelsen, jeg fikk til noe. Det var ikke lenger frykt, men nysgjerrighet som dukket frem når jeg åpnet en ukjent journal

Rundt uke fire i praksis hadde noe endret seg. Dag for dag, konsultasjon for konsultasjon hadde utryggheten blitt slipt ned. Jeg hadde bitt skammen i meg. Jeg hadde gang på gang inntatt legerollen, latt som om utryggheten ikke eksisterte, tatt meg sammen, vist interesse for disse pasientene og med gradvis stødigere hender og flere diagnostiske teorier $\mathrm{i}$ bakhodet undersøkt og vurdert dem. Jeg hadde strevd, slått opp, prøvd meg på egne forslag - som noen ganger hadde vært rett. Oftere kjente jeg at det ikke gikk så aller verst. En dag merket jeg at jeg faktisk tok ledelsen, jeg fikk til noe. Det var ikke lenger frykt, men nysgjerrighet som dukket frem når jeg åpnet en ukjent journal. En omsorgsfull veileder ga meg mot. En gang sa han at pasientene hadde stjerner i øynene etter å ha snakket med meg. Da kjente jeg at noe hadde skjedd.

Praksis gir kunnskap, men enda viktigere: identitet

Overgangsriter innebærer tap av gammel identitet, usikker famling med den man ennå ikke er blitt, og - hvis man overlever - tilbakevending som et nytt menneske. Det jeg gjorde gjennom seks uker på et legekontor, var å oppdage meg selv som lege og ikke lenger bedrager. Det skjedde i det tilsynelatende banale, som å stille diagnosen bilateral otitis media på en gråtende ettåring etter ett sekunds otoskopi, å velge antibiotika og regne ut vektbasert dosering. At veilederen kun trengte å trykke «send» på resepten, kjentes som et trylleslag.

Hvis noen spør hvordan allmennpraksis var, svarer jeg «magisk». Jeg er blitt ledet til et nytt sted, til et nytt «jeg». Følelsen av utilstrekkelighet har forsvunnet, tross en uendelig liste med sykdommer jeg må lese mer på. Praksis gir kunnskap, men enda viktigere: identitet. Nå kan turnustiden bare komme. Jeg er ikke ferdig utlært, men jeg er ferdig med å være utrygg hver gang jeg blir usikker.

Publisert: 11. januar 2021. Tidsskr Nor Legeforen. DOI: 10.4045/tidsskr.20.0894

(C) Tidsskrift for Den norske legeforening 2020. Lastet ned fra tidsskriftet.no 